\title{
РОЛЬ ІНФОРМАЦІЙНОГО ЗАБЕЗПЕЧЕННЯ ДИПЛОМАТИЧНОЇ ДІЯЛЬНОСТІ В УМОВАХ ГЛОБАЛІЗАЦІЙНИХ ПРОЦЕСІВ СУЧАСНОСТІ
}

\section{Андрієнко Петро Павлович}

Надзвичайний і Повноважний Посланник, кандидат технічних наук, доцент,

Київський національний університет культури і мистецтв, м. Київ, Україна

\section{Сарапін Ганна Анатоліївна}

кандидат наук із соціальних комунікацій,

Київський національний університет культури і мистецтв,

м. Київ, Україна

ORCID: 0000-0003-4009-5481

annaonline5@gmail.com
Надіслано:

11.03.2021

Рецензовано:

20.03.2021

Прийнято:

05.04.2021

Винахід нових технологій, переважно в галузі телекомунікацій: телефон, радіо, телебачення та супутниковий зв'язок - суттєво вплинули на дипломатію, проте не замінили саму природу здійснення дипломатичних процедур. У свою чергу, комунікація та інформація, основні стовпи дипломатії, за останні роки були принципово змінені шляхом процесу цифровізації. У сучасному житті роль і місце інформації без перебільшення можна визначити як одне з найважливіших. Людство давно усвідомило, що успіх будь-якої практичної діяльності визначається багатьма факторами, але перш за все, якістю інформаційного забезпечення. Недостатня кількість, ігнорування наявної інформації, або нездатність правильно ї̈ оцінити рано чи пізно можуть стати причиною серйозних прорахунків і помилок, які врешті-решт призведуть до глибокої поразки на дипломатичній арені. Метою статті є дослідити вплив сучасних цифрових інформаційно-комунікативних технологій на розвиток і практику здійснення дипломатичної служби держави. Методологія дослідження є комплексною і визначається специфікою предмета дослідження, його метою і завданнями, а також міждисциплінарним підходом до визначеної проблеми. У результаті зроблено висновки, що новітня комунікаційна еволюція не тільки пришвидшила потік інформації, але й розширила ментальність

(С)Андрієнко П. П., Сарапін Г. А., 2021 
та способи мислення в дипломатичному співтоваристві. Дипломату постійно доводиться ретельно та безперервно аналізувати події, інформацію про які він отримує зі своїх спеціальних джерел, які, в свою чергу, можуть вплинути на процес формування не тільки його думки, але і внутрішньої / зовнішньої політики в цілому.

Ключові слова: дипломатія; дипломатична служба; інформація; інформаційно-комунікативні технології; глобалізаційні процеси.

\section{Вступ}

Досягнення сучасного рівня розвитку інформаційних технологій сприяло стиранню кордонів між державами в комунікаційному просторі, створення безпрецедентних можливостей для впливу на величезні маси людей із застосуванням різного роду інформаційних засобів і методів. В умовах формування глобального інформаційного простору світове співтовариство дедалі активніше стало використовувати інформацію як знаряддя досягнення переваги в різних сферах життя суспільства - соціальної, економічної, духовної, але перш за все - у політичній. У всьому спектрі наукової проблематики, що має відношення до ефективності інформаційного забезпечення зовнішньополітичної діяльності, можна виділити наступні аспекти: міжнародні відносини в епоху формування глобального інформаційного суспільства; розвиток сучасних форм і засобів міжнародної політичної комунікації; забезпечення зовнішньополітичної (в тому числі інформаційної) безпеки України за сучасних умов; діяльність дипломатичних служб та інших зовнішньополітичних відомств України та зарубіжних країн. Однак у даному випадку слід зосередити увагу насамперед на тих розробках, які безпосередньо пов'язані з проблемами розвитку дипломатичної комунікації в сучасному інформаційному суспільстві.

\section{Аналіз останніх досліджень і публікацій}

Як вітчизняні, так і зарубіжні політологи в останні роки приділяли багато уваги науковій розробці проблем, пов'язаних 3 розвитком інформаційнокомунікаційних технологій. При цьому, якщо поняття «інформаційне суспільство» і його фактична тотожність із категорією «постіндустріальне суспільство» у політичній науці можна вважати встановленим, то зміст таких взаємопов'язаних із ними категорій як «інформаційні аспекти політичної комунікації» або «інформаційно-комунікаційні технології» ще остаточно не $\epsilon$ визначеним. Характеризуючи ступінь вивченості проблем інформаційного забезпечення дипломатичної діяльності, особливу увагу необхідно приділити 


\section{Міжнародні відносини: теоретико-практичні аспекти \\ Випуск 7 (2021) \\ ISSN (print) 2616-745X; ISSN (online) 2616-7794}

працям тих учених, які досліджують форми і методи інформаційної активності на міжнародній арені (гуманітарна інтервенція, інформаційні війни, ресурс «м'якої сили» тощо). Проблеми забезпечення інформаційної безпеки окремих акторів міжнародних відносин. В Україні в цьому напрямі цікавими

$\epsilon$ напрацювання Ю. Левенця, Г. Почепцова, В. Королька, Л. Нагорної, О. Зернецької, В. Литвиненка, М. Ожевана та ін.

3 теоретичного погляду важливим також $є$ те, що феномен комунікації поєднує в єдине ціле категорії інтеракції (взаємодії) та інформації. Комунікація не $є$ просто зв'язком чи каналом передачі інформації, вона виступає тією ланкою, без якої неможливе ані протікання, ані розуміння будь-яких суспільнополітичних процесів (Kovalevskyi, 2009).

\section{Формулювання цілей статті}

Метою статті є дослідження аспектів розвитку інформаційної роботи дипломатичної служби держави в умовах розвитку глобалізації сучасного суспільства, її систематизації. Нині неможливо розглядати розвиток сучасного громадянського суспільства без розвитку цифрових інформаційнокомунікаційних технологій.

\section{Виклад основного матеріалу дослідження}

Англійський дипломат Г. Нікольсон стверджує, що дипломатія є наукою писемною (Nikolson, 1998, р. 88). Такої думки дотримується і наукова школа В. Попова, «дипломатія значною мірою $\epsilon$ мистецтвом і вмінням писати» (Popov, 2003, р. 411).

Традиційна дипломатія практикується як мистецтво та мистецтво спілкування та взаємозв'язку між державами, що діють через своїх представників (дипломатів) у національних інтересах (політичних, економічних, наукових, соціальних тощо) мирними засобами. Ці засоби не виключають використання (політичного чи економічного) тиску, який визначається як примусова дипломатія. 3 метою організації та покращення діалогу між державами i, таким чином, оптимізації змісту та якості міжнародних відносин, дипломатія вдається до використання т. зв. соціальної практики, а саме: певного набору навичок, інструментів, процедур, методів, норм і правил. Загальновизнаною правовою базою цієї практики є Віденська конвенція про дипломатичні відносини (1961) (Videnska konventsiia pro dyplomatychni znosyny, 1961) та Віденська конвенція про консульські відносини (1963) (Videnska Konventsiia pro konsulski znosyny, 1963), а також міжнародне звичаєве право. Важливу частину цих правил складає протокол як настанова щодо упорядкованої офіційної чи представницької поведінки дипломатів.

(САндрієнко П. П., Сарапін Г. А., 2021 


\section{Андрієнко Петро Павлович, Сарапін Ганна Анатоліївна \\ Роль інформаційного забезпечення дипломатичної діяльності \\ в умовах глобалізаційних процесів сучасності}

Ці документи дипломатичного обміну є усними чи письмовими (Essentials of modern diplomacy).

Починаючи із др. пол. XX ст. із появою нових складних проблем у галузі озброєння, економіки, екології, освоєння морського простору, прав людини, а також виникнення нових міждержавних стосунків, паралельно виникли й нові вимоги до дипломатичної інформації. Значно збільшився обсяг інформації з міжнародних проблем і особливо в засобах масової інформації. Усьому цьому сприяв динамічний розвиток електронних засобів зв'язку й комп'ютерної техніки.

Протягом всієї історії технології значним чином впливали на людське суспільство, його економічні, політичні відносини, соціальні та культурні відносини та цінності, тому і сучасні міжнародні відносини розвиваються в умовах стрімкого розвитку комп'ютерних технологій і процесів глобалізації. Вступ цивілізованого світу в інформаційну епоху, яка викликала зростання ролі інформації та інформаційних технологій (IKT) у всіх сферах суспільного життя, включаючи політику, сприяло розробці і впровадженню нових інструментів позиціонування держав на міжнародній арені, а так само - нових способів досягнення політичними акторами своїх стратегічних цілей. Основною сферою апробації і застосування цих інструментів стала політична комунікація найважливіше на нинішній день знаряддя політичної конкуренції (Melnikova, 2020).

Однак саме з появою інтернету ІКТ набули зовсім іншого значення. Інтернет не тільки ще більше полегшив спілкування, але також забезпечив майже повсюдний доступ до інформації, що дозволило людям по всьому світу співпрацювати, створювати спільноти, робити бізнес, вчитися, розважати і навіть мати «віртуальне життя». ІКТ надали громадянам можливість брати активну участь у місцевих та міжнародних процесах формування політики, а отже, суттєво впливати на міжнародні відносини та ведення дипломатії.

У свою чергу, сучасна дипломатія реалізується різними шляхами під керівництвом не лише президентів і прем'єр-міністрів, а також і юристів, науковців, економістів, працівників гуманітарних служб i, звичайно, послів. Вони являють собою різноманітність потенційних дипломатичних акторів, разом утворюючи той зв'язок, який можна назвати «дипломатичним стилем»сукупність зусиль щодо збільшення владного впливу за допомогою інноваційних партнерських відносин та стратегій, а не односторонніх актів сили (Hutchings, Suri, 2015). У XXI ст. міжнародна політика налічує широкий спектр міжнародних суб'єктів, включаючи держави, етнонаціоналістичні фактори, транснаціональні корпорації, міжурядові організації, неурядові 


\section{Міжнародні відносини: теоретико-практичні аспекти \\ Випуск 7 (2021) \\ ISSN (print) 2616-745X; ISSN (online) 2616-7794}

організації, різні транснаціональні рухи та мережі або навіть приватних осіб (Mingst, 2008). Швидке зростання цієї мережі, а також інтенсивна та зростаюча комунікація та взаємодія всередині неї є показниками зростання міжнародної взаємозалежності. Й хоча цифрова дипломатія не замінює традиційну дипломатію, але вона швидко та ефективніше посилює роботу держави уміжнародних відносинах. Тому дипломатична практика не залишилася осторонь від цих процесів: з'явилася концепція «прямих комунікацій», яка наразі дозволяє найвищим посадовим особам спілкуватися безпосередньо один з одним без посередників (Berridge, 2002).

Винахід служби електронної пошти (e-mail) та ї̈ більш широке використання з кінця 90-х рр. ХХ ст. уже виявили величезний потенціал електронних повідомлень. Довгі листи могли бути легко надіслані майже в реальному часі одному чи кільком одержувачам одночасно. Однак така зручність також змінила звичку спілкуватися через повідомлення, змушуючи користувачів часто зменшувати вміст до кількох речень або навіть слів, одночасно збільшуючи загальний обсяг і частоту спілкування електронною поштою до рівня майже 250 млрд - щоденні обміни повідомленнями по всьому світу (Internet 2009 in numbers, 2010). На відміну від електронної пошти, використання миттєвих месенджерів, подальших голосових і відеодзвінків через інтернет - наприклад, Skype - стало загальнодоступним варіантом дипломатичного спілкування в реальному часі.

У зв'язку з тим, що значна частина дипломатичних установ приєдналися до системи «Інтернет», зросли й вимоги до аналітичної роботи дипломатів. Відповідно до чинних норм, дипломатична інформація обов'язково повинна носити інформативний характер і базуватись на обліку й глибокому вивченні широкого ряду факторів, що стосуються тієї чи іншої проблеми. Також на основі реальної картини сьогодення дипломат повинен передбачити розвиток подій у майбутньому та надати власні рекомендації стосовно подальших дій, тому сучасна дипломатична інформація має грунтуватися на численних джерелах і бути достовірною, актуальною та неупередженою.

Нині можна констатувати, що інформація - це сукупність даних про внутрішній і зовнішній стан адміністративної системи, використаних для оцінки ситуації й вироблення управлінських рішень.

(САндрієнко П. П., Сарапін Г. А., 2021 
Інформація має ряд цінних властивостей (Torkunova, Panova, 2014), a саме:

- актуальність;

- накопиченість;

- рухомість;

- збереження при рухомості;

- комунікативність (можливість її передачі);

- висока цінність.

Це ствердження стосується, не лише інформації про економічний чи оборонний стан держави, але й інформації про науково-технічний, політичний, соціально-гуманітарний стан держави чи будь-якої іншої важливої інформації.

Саме тому у міжнародних відносинах i дипломатії повнота, достовірність, своєчасність і точність інформації вкрай необхідні для правильної оцінки сили та впливу держави, iㅣ можливостей і міжнародного потенціалу.

Покладена на папір інформація вважається документом, який може бути використаний у дипломатичних цілях. Останні, у свою чергу можна умовно розділити на дві категорії. До першої категорії можна віднести документи, що направляються керівництву МЗС для забезпечення інформаційної функції. До другої категорії можна віднести документи, що використовуються для прийняття рішень і реалізації конкретних заходів.

Головною рисою, притаманною дипломатичним документам $\epsilon$ те, що вони $\epsilon$ записом політичної та дипломатичної інформації, виконаної в залежності від епохи на різних носіях відповідно до визначених правил з метою i подальшого використання в практичній роботі. Дипломатична служба у своїй діяльності має справу з різними типами документів. У цілому їх можна розділити на дві категорії: a) внутрішньовідомчі документи; б) документи зовнішнього дипломатичного листування, що використовуються в дипломатичному листуванні з представниками-партнерами інших держав.

До першої категорії відносяться документи, що забезпечують діяльність органів державної влади, Міністерства закордонних справ, різних відомств, організацій і установ у сфері зовнішньої політики та міждержавних зносин. До другої категорії відносяться офіційні документи за допомогою яких здійснюються письмові контакти між державами та іншими суб'єктами міждержавних відносин.

Дипломатична документація - це важлива невіддільна складова дипломатичної роботи, оскільки вона $є$ основним інструментом здійснення 


\section{Міжнародні відносини: теоретико-практичні аспекти \\ Випуск 7 (2021) \\ ISSN (print) 2616-745X; ISSN (online) 2616-7794}

зовнішньої політики держави. Будь-який дипломатичний документ - це, перш за все, «державний» документ. По офіційному дипломатичному документу можна оцінити не лише зовнішню політику держави, але й професійність дипломатичної служби, досвідченість, злагодженість державного апарату, рівень підготовки окремого дипломата тощо.

Проте слід зауважити, що дипломатичні документи досить часто мають упереджувальний характер. Упередження може мати місце при а) аргументації партнера в захисті своєї точки зору в рамках національних інтересів; б) аргументації на користь своєї точки зору при висвітленні окремих питань чи подій; в) аргументації на користь своєї точки зору з метою попередити вагомість доводів партнера (противника), ослабити їх вплив.

Для якісного та коректного трактування дипломатичних документів обов'язково необхідно добре володіти інформацією, знати точку зору різних сторін, уміти передбачити контраргументи партнера та довести, що ваші пропозиції та позиція не є суб'єктивними та не обмежують інтереси інших сторін. При цьому бажано привести у якості контраргументів такі факти та дані проти яких було б важко заперечити.

Актуальність подій, об’єктивність, правдивість, конфіденційність, оперативність і таємність дипломатичної інформації закордонних країн стали поштовхом до винайдення та (використання) впровадження технічних засобів спеціальними службами у всіх країнах світу.

У кожній країні світу існують власні національні радіо й телевізійні компанії, які постійно транслюють новинні блоки. Крім того, в іноземних державах виходять десятки локальних радіостанції, які передають регіональні та місцеві новини. Усі дипломатичні працівники починаючи з самого ранку, ще до початку роботи слухають і дивляться новинні блоки місцевого радіо й телебачення (Nikolson, 1998, p.88). У багатьох із них у робочому кабінеті дипломатичної установи, вдома, в автомобілі завжди включені радіоприймачі.

У гонитві за оперативністю або сенсаційністю теле- і радіокомпанії досить часто дають не завжди точну, а інколи навіть i не перевірену інформацію. Дипломат, у свою чергу, зобов'язаний перевіряти здобуту інформацію, звіряти 3 іншими наявними джерелами та предметно досліджувати ситуацію. Крім того, у деяких державах (зазвичай тих, що розвиваються) у критичні моменти (захоплення влади, або під час масових виступів чи демонстрації населення, землетрусів) місцеве телебачення та радіо на якийсь час можуть бути єдиним джерелом оперативної інформації, якщо події протікають далеко від столиці.

(С)Андрієнко П. П., Сарапін Г. А., 2021 


\section{Андрієнко Петро Павлович, Сарапін Ганна Анатоліївна \\ Роль інформаційного забезпечення дипломатичної діяльності в умовах глобалізаційних процесів сучасності}

У вищезазначених випадках репортери зазвичай переходять на національну мову й така оперативна інформація стає єдиним джерелом інформації. У цій ситуації наявність у дипломатичному представництві фахівця, котрий вільно володіє місцевою мовою (більше, ніж 2 особи) $є$ вкрай необхідною.

Наступним джерелом актуальної інформації $є$ газети, що виходить у країні перебування щоденно. У них, зазвичай, більш грунтовно й розгорнуто висвітлюється аналіз різних події та питань. Робочий день дипломатичних представників у країні перебування розпочинається з читання місцевих газет. Інформацію, подану в газетах дипломати намагаються читати декілька разів, щоб не пропустити важливих моментів, особливостей і навіть натяків. Крім того, необхідно пам'ятати, що розміщена у газеті стаття, висловлювання, або коментарі можуть бути «замовленням», викладати перекручені дані, неповну чи неточну інформацію, навмисно містити дезінформацію.

Необхідною якістю дипломатичної інформації є її новизна. Кожний інформаційний матеріал повинен мати нові невідомі аспекти, наприклад, описувати нові політичні нюанси, висвітлювати останні події, появу у суспільстві нових сил і політичних діячів, лідерів, які можуть додатково вплинути на події, а тим самим і на безпеку держави.

Елементи новизни можуть з'являтися безперервно. Усе це залежить від подій в країні перебування, зміни й розставляння сил, зміни політичних подій та зміни політичних тенденцій, а також дії сил, які знаходяться при владі. Відслідковування та реакція на внутрішньополітичні події, зміни в різних сферах життя країни являється зобов'язанням закордонної дипломатичної служби в країні перебування.

Особливу цінність дипломатична інформація представляє тоді, коли вона має конфіденційний довірливий характер, прояснює факти та події, що відбуваються у т. зв. закритій зоні, яка оберігається від втручання та уваги зовнішніх сил, окремих особистостей і ЗМІ.

Конфіденційність - це система роботи з інформацією,що забезпечує відсутність відкритого доступу до того, що повинно бути відомо тільки обмеженому колу осіб. До ряду конфіденційної інформації можуть відноситися довідка або дані про положення правлячої еліти країни перебування; присутність «третіх» керівників держави; окремі зв'язки та взаємовідносини між різними центрами або окремими групами впливу; зв'язки політичними діячами, бізнесом і чинною владою тощо. Не менш конфіденційною може бути й інформація про методи управління в державі, засоби масової інформації, 


\section{Міжнародні відносини: теоретико-практичні аспекти \\ Випуск 7 (2021) \\ ISSN (print) 2616-745X; ISSN (online) 2616-7794}

про стан здоров'я глав держав і урядів, про діяльності «тіньових кабінетів», закритих «коридорів влади».

Збереження конфіденційності забезпечується «режимом таємності». Насправді мова йде про систему установлених норм, правил і традицій, які визначають порядок і умови забезпечення та збереження в таємності інформації, що містить таємний характер і державну та/або службову таємницю.

Зрозуміло, що перш, ніж конкретні політичні плани й наміри будуть викладені на папір і отримають обмежувальні грифи, вони проходять довгий період обговорення на рівні ідей, пропозицій, концепцій. Одночасно, до їх обговорення залучаються представники громадськості суспільства, групи провідних спеціалістів. Відслідковувати тенденції, передбачити майбутні зміни, спрогнозувати подальшу державну політику країни перебування $\epsilon$ надзвичайно важливим питанням для дипломатичного представника.

Слід пам'ятати, що будь-яка важлива інформація повинна бути викладена лаконічно й зрозуміло. Повторення, нечіткість викладання думки, плутанина $€$ неприйнятними для дипломатичного документа. Тому кожний дипломат повинен володіти національною мовою, мати літературний талант, вміти знайти потрібні слова й висловити власні думки так, щоб коротко, але вичерпно викласти суть питання. При складанні шифрограм або доповідних записок керівництву завжди необхідно прагнути, щоб:

-у максимально стислій формі розповісти про джерело виникнення проблеми;

- вичерпно й максимально об’єктивно оцінити стан проблеми на даний момент;

- коротко охарактеризувати основних учасників подій, сторін залучених до проблеми;

- звернути увагу на можливі політичні наслідки даних подій;

- виразити основні тенденції проблеми, представити прогноз їх розвитку в найближчій або більш віддаленій перспективі;

- звернути увагу на значущість проблеми з точки зору національних інтересів держави.

Інколи після підготовки інформаційних матеріалів для доповіді керівництву залишається почуття сумніву відносно достовірності, про це обов'язково необхідно сказати керівництву.

(САндрієнко П. П., Сарапін Г. А., 2021 


\section{Андрієнко Петро Павлович, Сарапін Ганна Анатоліївна \\ Роль інформаційного забезпечення дипломатичної діяльності \\ в умовах глобалізаційних процесів сучасності}

Наступною головною якістю дипломатичної інформації являється iii об'єктивність і достовірність. Правдивість і об'єктивність інформації являється обов'язковою вимогою професійного відношення дипломата до своєї службової діяльності та $€$ важливим критерієм оцінки, інформації, яку доповідає дипломат. Практика показує, що об’єктивність і достовірність інформації являється показником успішної роботи зовнішньополітичної установи та забезпечує національну безпеку держави.

Як нами вже неодноразово зазначалося вище, для подання достовірної інформації необхідно отримувати їі з багатьох незалежних джерел. У зв'язку з цим при отриманні цінної інформації (такої, що має важливе міжнародне значення) або забезпечуючи безпеку держави, МЗС держави залишає за собою право перевірити, уточнитий підтвердити будь-яку надану інформацію. Найбільше порушеної проблеми стосується достовірність таких джерел як підписані документи, тексти договорів, угод, заяв і матеріали заяв ключових осіб держави.

Ще однією важливою вимогою до складання дипломатичної інформації $\epsilon$ їі повнота. У якому вигляді вона не подавалась вищому керівництву (шифрограми, письмове повідомлення, усна доповідь), інформація повинна бути максимально повною й усесторонньою. Матеріал інформації необхідно викласти таким чином, щоб при ознайомлені в читача не виникало додаткових запитань. Тобто інформація повинна давати повне, вичерпне уявлення про події та питання, які висвітлюються.

Найбільшу цінність має дипломатична інформація яка носить попереджуючий характер i покликана запобігти назріванню проблем i конфліктів. Її особлива цінність полягає в тому що вона допомагає сформувати думку й реакцію держави на окремі події та питання, що тільки виникають або мають потенційний характер. У свою чергу, інформація яка носить попереджуючий характер дає змогу вжити попередніх або фактичних заходів і забезпечити грамотне та високоефективне рішення не лише існуючої проблеми, але й проблем стратегічного характеру.

Крім інформації отриманої із-за кордону дипломатичним працівникам надходить значний обсяг службової інформації з різних джерел. Це можуть бути аналітичні матеріали, підготовлені іншими територіальними й функціональними підрозділами МЗС; директивні матеріали 3 адміністрації президента й апарату уряду держави; службові й інформаційні матеріали, підготовлені іншими міністерствами та відомствами держави тощо. 


\section{Міжнародні відносини: теоретико-практичні аспекти \\ Випуск 7 (2021) \\ ISSN (print) 2616-745X; ISSN (online) 2616-7794}

Це дозволяє дипломатом бути в курсі останніх подій і актуальних питань держави, і відповідно вибудовувати власну професійну діяльність.

Важлива інформація також надходить від ради безпеки, зовнішньої та контррозвідки, прикордонних служб, митної служби та міністерства внутрішніх справ. Багато корисних відомству ідей знаходиться в документах, підготовлених науковими аналітичними центрами, представниками експертних центрів. Окрім службової інформації працівники зовнішньополітичної установи використовують у своїй роботі й загальнодоступну інформацію, отриману з новинних стрічок, інформаційних агентств, газет, журналів, офіційних веб-сайтів і мережі «Інтернет». Для об’єктивної оцінки ситуації і прийняття правильного та обгрунтованого рішення уряду держави життєво необхідно володіти достовірною, своєчасною та максимально повною інформацією.

Пошук i збір інформації законними способами супроводжується складанням дипломатичних документів з представниками іноземних держав, офіційного й особистого листування, внутрішньовідомчого листування (між МЗС і посольствами своєї країни, президентом, урядом та іншими міністерствами й відомствами). Саме ця частина роботи займає $80 \%$ часу дипломатів вищих і середніх рангів міністерств і більше половини робочого часу дипломатів, які працюють у закордонних установах (Popov, 2003, p. 432).

\section{Висновки}

Нині завдяки глобалізаційним процесам зростає кількість учасників: субдержавні утворення (місцеві та регіональні) НУО, транснаціональні компанії, засоби масової інформації , наукові кола, фонди, політичні партії тощо), тобто, зовнішня політика у більш широкому розумінні здійснюється не лише державами через своїх представників, але й будь-ким із цих нових учасників. У свою чергу, до реалізації дипломатичних відносин залучається набагато більше партнерів, аніж раніше, тому дипломатія стає все більше приватизованою та популяризованою практикою.

Дипломатія за своєю суттю є постійним процесом, який нелегко піддається короткостроковості. Для дипломатії потрібні знання, судження та досвід, що, у свою чергу, зумовлює необхідність адаптації до навколишнього світу. Ця адаптація не є питанням вибору, а необхідністю. Технологія впливає не тільки на те, як дипломати ведуть бізнес, але і на те, що таке бізнес дипломатії.

Новітня комунікаційна еволюція не тільки пришвидшила потік інформації, але й розширила ментальність та способи мислення 


\section{Андрієнко Петро Павлович, Сарапін Ганна Анатоліївна \\ Роль інформаційного забезпечення дипломатичної діяльності \\ в умовах глобалізаційних процесів сучасності}

в дипломатичному співтоваристві. Дипломату постійно доводиться аналізувати події з глибокою якістю та безперервністю своїх спеціальних та широко розповсюджених джерел, які можуть впливати на внутрішню думку, а також на процес формування внутрішньої політики.

Незважаючи на будь-які нові технології, такі як електронна пошта, факс чи телефон, ніщо насправді не може замінити особистий контакт та діалог, підтверджений рукостисканням. 3 іншого боку, будь-яка дипломатична ініціатива та діяльність на місцях може постійно контролюватися його адміністрацією вдома, яка може надавати більш детальні інструкції та навіть інструкції в режимі реального часу відповідно до внутрішніх інтересів.

Отже, цифровізація та розширення сфери IКТ наприкінці XX - поч. XXI ст. стали революцією у сфері дипломатії, оскільки вони кардинальним чином вплинули на розвиток сучасної дипломатичної практики, управління інформацією, публічної дипломатії, стратегічного планування, міжнародних переговорів та антикризового управління, набуваючи ознак т. зв. цифрової дипломатії, яка використовує IКТ, інтернет та соціальні медіа для зміцнення дипломатичних відносин.

\section{References:}

1. Berridge, G.R. (2002). Diplomacy: theory and practice. Basingstoke: Palgrave.

2. Essentials of modern diplomacy. Part 1, [online]. Available at: https://www.google.com/url?sa=t\&rct=j\&q=\&esrc=s\&source=web\&cd=\&cad=rja\&ua ct=8\&ved=2ahUKEwj6kZO_renuAhUnlIsKHRrCAgQQFjACegQIARAC\&url=https\%3A\% 2F\%2Flink.springer.com\%2Fcontent\%2Fpdf\%2Fbfm\%253A978-3-540-711018\%252F2\%252F1.pdf\&usg=A0vVaw2lZ7YfEm-2qQar6fecera7.

3. Hutchings, R. \& Suri, J. (2015). Foreign Policy Breakthroughs: Cases in Successful Diplomacy . Oxford University Press.

4. 'Internet 2009 in numbers'. (2010). Royal Pingdom, [online]. Available at: http://royal.pingdom.com/2010/01/22/internet-2009-in-numbers/.

5. Kovalevskyi, V. O. (2009). 'Struktura politychnykh komunikatsii suchasnoi Ukrainy' [The structure of political communications in modern Ukraine]. Suchasna ukrainska polityka. Polityky i politolohy pro nei [Modern Ukrainian politics. Politicians and political scientists about it], issue 17, pp.137-144.

6. Melnikova, O. A. (2020). Informatsionnoe obespechenie vneshnepoliticheskoi deyatel'nosti sovremennykh gosudarstv (politologicheskii analiz) [Information support of the foreign policy of modern states (political science analysis) ]. D.Ed. Diplomatic Academy of the Ministry of Foreign Relations of the Russian Federation. 
7. Mingst, A.K. (2008). Bazat e Marrëdhënieve Ndërkombëtare. Tiranë: Albanian Institute for International Studies.

8. Nikolson, H. (1998). Dyplomatiia [Diplomacy]. Translated from English by A. A. Troyanovskii. Kyiv : Tri krapki.

9. Popov, V. I. (2003). Sovremennaya diplomatiya [Modern Diplomacy]. Moscow: Nauchnaya kniga.

10. Torkunova, A. V., Panova, A. N., eds. (2014). Diplomaticheskaya sluzhba [Diplomatic service]. Moscow State Instuitute of International relations-UniversityMoscow: Aspekt Press.

11. Videnska konventsiia pro dyplomatychni znosyny: OON; Konventsiia, Mizhnarodnyi dokument pryiniatyi 18 kvitnia 1961 roku № 995_048 [Vienna Convention on Diplomatic Relations: UN, Convention, International Document dated from April 18, 1961, № 995_048]. Verkhovna Rada Ukrainy, [online]. Available at: https://zakon.rada.gov.ua/laws/show/995_048\#Text.

12. Videnska Konventsiia pro konsulski znosyny OON; Konventsiia, Mizhnarodnyi dokument pryiniatyi 24 kvitnia 1963 roku № 995_047 [Vienna Convention on Consular Relations: UN, Convention, International Document dated from April 24, 1963, № 995_047]. Verkhovna Rada Ukrainy, [online]. Available at: https://zakon.rada.gov.ua/laws/show/995_047\#Text.

(САндрієнко П. П., Сарапін Г. А., 2021 


\title{
THE ROLE OF THE DIPLOMATIC ACTIVITY'S INFORMATION SUPPORT IN THE MODERN GLOBALIZATION PROCESSES
}

\author{
Andriienko Petro \\ Envoy Extraordinary and Minister Plenipotentiary, \\ Candidate of Technical Sciences, Associate Professor, \\ Kyiv National University of Culture and Arts, Kyiv, Ukraine;
}

\author{
Sarapin Hanna \\ Candidate of Sciences in Social Communications, \\ Kyiv National University of Culture and Arts, \\ Kyiv, Ukraine \\ ORCID: 0000-0003-4009-5481 \\ annaonline5@gmail.com
}

The invention of new technologies, mainly in the field of telecommunications: telephone, radio, television and satellite communications, had a significant impact on diplomacy, but did not replace the very nature of diplomatic procedures. In turn, communication and information, the main pillars of diplomacy, have been fundamentally changed in recent years through the process of digitization. In modern life, the role and place of information without exaggeration can be defined as one of the most important. Humanity has long realized that the success of any practical activity is determined by many factors, but above all the quality of information support. Insufficient amount, ignoring of available information or inability to evaluate it correctly can eventually lead to serious miscalculations and mistakes, which will eventually lead to deep defeat in the diplomatic arena. The aim of the article is to investigate the impact of modern digital information and communication technologies on the development and practice of the state's diplomatic service. The research methodology is complex and is determined by the specifics of the research subject, its purpose and objectives, as well as an interdisciplinary approach to a particular problem. As a result, it was concluded that the latest communication evolution has not only accelerated the flow of information, but also expanded the mentality and ways of thinking in the diplomatic community. The diplomat constantly has to carefully and continuously analyze the events, information about which he receives from his special sources, which, in turn, can affect the process of forming not only his opinion, but also domestic / foreign policy in general.

Key words: diplomacy; diplomatic service; information; information and communication technologies; globalization processes. 


\title{
РОЛЬ ИНФОРМАЦИОННОГО ОБЕСПЕЧЕНИЯ ДИПЛОМАТИЧЕСКОЙ ДЕЯТЕЛЬНОСТИ В УСЛОВИЯХ ГЛОБАЛИЗАЦИОННЫХ ПРОЦЕССОВ СОВРЕМЕННОСТИ
}

\author{
Андриенко Петр Павлович \\ Чрезвычайный и Полномочный Посланник, \\ кандидат технических наук, доцент, \\ Киевский национальный университет культуры и искусств, г. Киев, Украина
}

\section{Сарапин Анна Анатольевна}

кандидат наук по социальным коммуникациям, Киевский национальный университет культуры и искусств, 2. Киев, Украина ORCID: 0000-0003-4009-5481 annaonline5@gmail.com

Изобретение новых технологий, преимущественно в области телекоммуникаций: телефон, радио, телевидения и спутниковой святи существенно повлияли на дипломатию, однако не заменили саму природу осуществления дипломатических процедур. В свою очередь, коммуникация и информация, основные столбы дипломатии, кардинально изменились за последние годы под влиянием процесса цифровизации. В современной жизни роль и место информации без преувеличения можно определить как одни из важнейших. Человечество давно осознало, что успех любой практической деятельности определяется многими факторами, но прежде всего качеством информационного обеспечения. Недостаточное количество, игнорирование имеющейся информации, или неспособность правильно ее оценить рано или поздно могут стать причиной серьезных просчетов и ошибок, которые, в конце концов, приведут к поражению на дипломатической арене. Целью статьи является исследовать влияние современных цифровых информационно-коммуникативных технологий на развитие и практику осуществления дипломатической службы государства. Методология исследования является комплексной и определяется спецификой предмета исследования, его целью и задачами, а также междисциплинарным подходом копределенной проблеме. В результате исследования сделаны выводы, что новая коммуникационная эволюция не только ускорила поток информации, но и расширила ментальность и способы мышления

(C)Андрієнко П. П., Сарапін Г. А., 2021 
в дипломатическом сообществе. Дипломату постоянно приходится тщательно и непрерывно анализировать события, информацию о которых он получает из своих специальных источников, которые, в свою очередь, могут повлиять на процесс формирования не только его мнения, но и внутренней/внешней политики в целом.

Ключевые слова: дипломатия; дипломатическая служба; информация; информационно-коммуникативные технологии; глобализационные процессы. 